\title{
Assets Securitization Risk Management of Small Loan Companies in China
}

\author{
Jin-Mian Han, Jiang-Hai Qi \\ School of Economics and Management, Northwest University, Xi'an, China \\ E-mail: jinmianh@ nwu.edu.cn, qijianghai@ stumail.nwu.edu.cn
}

\begin{abstract}
The small loan companies play an important role in alleviating the financing difficulties of small and medium-sized enterprises in China, but they only make credit and cannot absorb public deposits, so they also face a shortage of funds. Asset securitization is an effective means for the financing of small loan companies. This kind of asset securitization also faces risks and its risk management is of great importance for such companies. After sorting and reviewing the domestic and foreign related research literature, this article identifies the risks in the process of asset securitization of small loan companies in China. Then it measures such risks, and finally puts forward risk management recommendations for the asset securitization of small loan companies in China.
\end{abstract}

Keywords-risk management; assets securitization; small loan company

\section{INTRODUCTION}

The first asset securitization product of the small loan companies in China called "Oriental securities asset management - Alibaba special asset management plan" initiated in July 2013. It not only creates asset securitization precedent of domestic small loan companies, but also provides experiences for other small loan companies to carry out their asset securitization. When the small loan companies set up in China, the government allowed the private to invest in the small loan company in order to ease the financing difficulties of small and medium-sized enterprises, and the main source of funds for small loan companies are shareholders' capital, donated funds and funds from no more than two financial institutions. They can't absorb public deposits. The situation that small loan companies "only making credit and absorbing no public deposits" makes them face great shortage of funds in the process of their middle and last period projects operation, so the small loan companies must explore and innovate their capital source channel. The asset securitization is an effective and feasible way to solve this problem.

In the academic research on asset securitization, the American investment banker Lewis Rainie (1977) first puts forward the concept of asset securitization, followed by related research scholars such as Schwarcz(1994), Claire(1996).At present the accepted definition of in theoretical circle is put forward by Shenker\&Colletta(1990). Benveniste and Berger (1987) consider that the most significant effect of asset securitization is that it can accomplish risk transfer. Through securitization behavior, the risk is transferred assets from the persons of risk aversion to risk preference or risk neutral investors, achieving a stable Pareto improvement. In the study of risk management of asset securitization, Jiang jianqing (2004) classifies the risk of asset securitization as systematic risk and non- systematic risk. Dunsky (2007) uses survival analysis to study the method of prepayment risk, it is concluded that in eliminating the influence of external factors, the early repayment rate remains the same. Newton (2008) et al. point out that when the account balance is greater than the market value of the corresponding mortgage, mortgage contract rate is greater than the current rate and prepayment risk will appear at this time. TaoTao (2013) classifies the risk of asset securitization as loss probability and loss severity, and use AHP method in quantitative research. Zhong-hetian, GuoXin (2012) identifies the risk of asset securitization, and use the VAR method to evaluate the risk.

In conclusion, the existing research on the risk of asset securitization, mostly analyzes one or several risks under rigid assumptions. But the asset securitization is over a period of time with more participants system. Although a specific risk may have great influence on the success of asset securitization, but the risk is not independent of each other. Under certain conditions, some hazards may also cause the occurrence of other risks and lead to the failure of the asset securitization. Besides, the study of the risk management of assets securitization small loan companies in China is rare. In view of this, this paper, taking the whole process of asset securitization of small loan companies as the research object, identifies the risks in the process of asset securitization, analyzes and measures the risks and puts forward suggestions for the risk management of asset securitization of China's small loan companies.

\section{THE PROCESS OF ASSETS SECURITIZATION AND ITS RISK IDENTIFICATION OF THE SMALL LOAN COMPANIES IN CHINA}

\section{A. The Process of Assets Securitization}

Before in risk identification, first of all, we need to clarify the process of asset securitization of the small loan companies. Through the analysis of the predecessors of asset securitization and combined with the actual situation of China's small loan companies, the general process of asset securitization of small loan company can be divided into three stages in this paper: the first stage is the originator, that is to say, the small loan companies build small credit assets that can be securitized (underlying asset package) and sold to the SPV institutions; the second stage is that after the credit enhancement, ratings and accounting, legal process assessment for asset securitization small loan portfolio, it is sold to investors; the third stage is and the trustees' management of small loan portfolio. 


\section{B. The Assets Securitization Risk Identification of the Small Loan Companies}

According to the characteristics of the asset securitization of small loan companies, this paper classifies its risks as external and internal risks. From the three stages, this paper identifies internal and external risk in different stages respectively,

At the first stage of the asset securitization of small loan companies, the external risks include macroeconomic risk, interest rate risk, policy risk, legal risk. The internal risk includes portfolio risk, namely the originator's improper combination of the underlying asset portfolio or the securities not matching will make the investors suffer the default risk of prepayment, which also affects the interests of the originator. The main source of income of the small loan company is the loan interest. They provide loan for small and medium-sized enterprises which may face operation and financial difficulties and cannot repay the money back, so the small loan companies face credit risk.

At the second stage of the asset securitization of small loan companies, the external risks include credit enhancement and the rating dropping for small loan portfolio from rating companies. The internal risk comprises redemption risk which shows that the debtor repay the loan ahead of schedule, or the payment within the prescribed period of time than the payment of the contract, which changes the cash flow of the asset pool in the process of asset securitization of the small loan companies, effects the original size, also influences the cash flow of asset-backed securities in the late process of asset securitization, and even may lead to the principal and interest not paying on time and causing losses to investors. The internal risk includes redemption risk, the hazard of which is that credit period of the small loan is generally short, and the credit itself is small. At greater risk of repayment ahead of schedule, the debtor makes small loan company term mismatch problem in the process of asset securitization, cause cash flow. Pricing risk, that is, because the asset securitization itself of the small loan company is the complex and a lot of factors need to be considered, the decision on the asset pricing is difficult and faces risks.

At the third stage of the asset securitization of small loan companies, the external risks include external economic environment risk, legal risk and regulation risk. The internal risks include services, trustee, and the change of the portfolio risk. The service level of the service intuition and the operation ability of the trustee will have an effect to benefits of the originator. The asset return may also be affected by the changes in portfolio, which also brings risk to the originator.

\section{THE MEASUREMENT OF CREDIT RISK AND REDEMPTION RISK OF ASSET SECURITIZATION OF SMALL LOAN COMPANIES IN CHINA.}

\section{A. Credit Risk Measurement}

We use KMV model to measure the credit risk of asset securitization of small loan companies. Assumes the distribution of discount of the underlying assets is normal distribution. The maturity date of the security is T. So on T day, the default condition of the asset securitization product can be expressed as V $(\mathrm{T})<\mathrm{BT}$. The income from underlying securitization assets $\mathrm{V}(\mathrm{T})$ is less than the liabilities BT. We also assume the probability of default is $\mathrm{p}$, and the fluctuation of the present value of underlying assets is $\sigma \mathrm{A}$. We get the following equation:

$$
\begin{gathered}
\mathrm{p}=\mathrm{P}\left[\mathrm{V}(\mathrm{T})<B_{T}\right] . \\
\mathrm{p}=\mathrm{P}\left[\mathrm{V}(\mathrm{T})<B_{T}\right]=P\left[\left(V(T)-B_{T}\right) / \sigma_{A}\right]<0 . \\
\mathrm{p}=\mathrm{N}\left[\left(V_{T}-B_{T}\right) / \sigma_{A}\right] .
\end{gathered}
$$

From the above formula, $p=\mathrm{N}(-\mathrm{DD})$.

We take Ali small loans as example to measure the credit risk. The pooling assets capital in the oriental securities asset management- Alibaba product 1 asset pool is 500 million RMB. The annual rate of a weighted average of the loan is $7.24 \%$. Assuming each asset is not related to one another in the asset package. The return rate of the principal and interest is only determined by the quality of assets, thus the return level of the principal and interest rate can indicate the changes in value of asset pool. Such as sequence interpolation processing is used to objectively describe the volatility of principal and interest recovery, we use sequence interpolation to objectively describe the change of the principal and interest return. According to the modified KMV model, we calculate: $\mu=0.047244903, \quad \delta=$ 0.113502578 .

We use the average return rate $98.5 \%$ of the principal and interest rate of Ali small loans from 2010 to 2012 as the expected return rate of the principal and interest rate. Assuming the period of the predicting default probability is 1 year. We use KMV model under the lognormal distribution to calculate the default distance and the default probability:

\begin{tabular}{|c|c|c|c|c|}
\hline \multirow{2}{*}{$\begin{array}{c}\text { Asset } \\
\text { size(One } \\
\text { Hundred } \\
\text { Million } \\
\text { RMB) }\end{array}$} & \multirow[t]{2}{*}{$\boldsymbol{\mu}$} & \multirow[t]{2}{*}{$\boldsymbol{\sigma}$} & $\begin{array}{l}\text { Default } \\
\text { distance }\end{array}$ & $\begin{array}{c}\text { Default } \\
\text { Probability }\end{array}$ \\
\hline & & & (DD) & (EDF) \\
\hline 5 & $\begin{array}{c}0.04724 \\
4903\end{array}$ & $\begin{array}{l}0.1135 \\
02578\end{array}$ & 2.98677 & 0.00141 \\
\hline
\end{tabular}

TABLE I. THE DEFAULT DISTANCE AND THE DEFAULT PROBABILITY

From the above calculation, the default probability Ali small loan assets is about $0.141 \%$. According to the rating standard of Shanghai Brilliance Credit Rating \& Investors Service Co., Ltd., $0.141 \%<0.25 \%$, the rating of the asset securitization product of Ali small loans is AAA. According to the information provided by Oriental securities asset management, the credit rating of Ali small loan special plan is also AAA, verifying the validity of the above calculation.

\section{B. Redemption Risk Measurement}

We use PSA (Public Securities Association) model to 
measure the redemption risk of asset securitization of small loan companies. PSA model sets a standard rate each month after issuing a loan called prepayment rate which is usually in the form of an annual rate. It cumulates 30 months, and starting from 31 months prepayment rate will remain constant. The basic situation is $100 \%$ PSA. The prepayment speed can be expressed by PSA percentage. After offering loans, the first month of the prepayment rate is $0.2 \% \mathrm{CPR}$ (constant prepayment rate). Then it increases by $0.2 \% \mathrm{CPR}$ in the following each months. The prepayment rate reaches $6 \%$ CPR in the 30th months. Then it will remain 6\% CPR constant. It can be expressed by the following piecewise function. $\{\mathrm{CPR}=6 \% *(\mathrm{~T} / 30), \mathrm{T} \leq 30 ; \mathrm{CPR}=6 \%, \mathrm{~T}>30\}(\mathrm{T}$ for the month)

We also take the oriental securities asset managementAlibaba product No.1 as an example to measure the redemption risk. Assuming that the cash inflow of Ali No. 1 prime asset-backed securities is as follows: the investors can receive $15 \%, 35 \%$ and $15 \%$ respectively of the principal and the expected return of the prime asset-backed securities within 7 days after the first, second and final distribution day. The specific cash flow is shown in the table below:

TABLE II. ALI NO. 1 PRIME ASSET-BACKED SECURITIES CASH INFLOW UNITS: RMB

\begin{tabular}{|c|c|c|c|c|c|}
\hline Product & $\begin{array}{c}\text { distributi } \\
\text { on date }\end{array}$ & $\begin{array}{c}\mathbf{t} \\
\text { valu } \\
\mathbf{e}\end{array}$ & $\begin{array}{c}\text { capital } \\
\text { inflow } \\
\text { s }\end{array}$ & $\begin{array}{c}\text { interest } \\
\text { inflow }\end{array}$ & the total \\
\hline $\begin{array}{c}\text { Ali 01 } \\
\text { prime } \\
\text { Asset-back } \\
\text { ed }\end{array}$ & $\begin{array}{c}2014 / 08 / \\
28\end{array}$ & 33 & 15 & 1.00750 & 16.00750 \\
\cline { 2 - 6 } & $\begin{array}{c}2014 / 09 / \\
28\end{array}$ & 37 & 35 & 0.25317 & 35.25317 \\
\cline { 2 - 6 } Securities & $\begin{array}{c}2014 / 10 / \\
28\end{array}$ & 32 & 50 & 3.87500 & 53.87500 \\
\hline
\end{tabular}

It can be seen from the Table 2 that the $\mathrm{t}$ value transferred to the month is less than $30, \mathrm{CPR}=6 \% *(\mathrm{t} / 30)$. The redemption rates of the three month are $1.54 \%, 1.73 \%$ and $1.49 \%$ respectively. All of these rates are far less than $6 \%$ of the early warning value, indicating a lower incidence of prepayment, a weak effect on the stability of the securitization cash flow, and the priority of assets division meeting the safety principle of prudent risk management.

Although the credit risk and redemption risk of Ali small loan measured by the models are relatively small, the parent company Alibaba is the nation's largest e-commerce company and Ali small loans as the first domestic asset securitization of small loan companies would minimize the risks. Compared with Ali, other small loan companies lack such advantages, and they may face many great uncertainties in the process of securitization, so they need comprehensive risk management.

\section{RECOMMENDATIONS FOR THE ASSETS SECURITIZATION RISK MANAGEMENT OF THE SMALL LOAN COMPANIES IN CHINA}

After identifying and analyzing the risks of asset securitization of the small loan company from three stages and measuring the credit risk and redemption risk of Ali small loan, this paper argues that the external risk of asset securitization of small companies needs to be transferred or avoided. The originator needs to determine the most advantageous time and way to issue after collecting and analyzing various kinds of information.

For its internal risks management in the process of asset securitization, at the first stage, after measuring the credit risk, the small loan companies should strengthen the credit check before providing a loan and credit review after providing the loan. They can also use a variety of means for risk early monitoring and develop a response plan. For portfolio risk, the small loan companies can let a professional institution help them to evaluate and improve the scheme of the portfolio on the basis of fully getting the real information of the lender. At the second stage, for the payment risk, they should protect the purchasing rights and pay prepayment penalties in advance paid to manage the risk. For the pricing risk, small loan companies can can comprehensively analyze the underlying assets and at the same time entrust a professional institution for evaluation. At the third stage, for the risk of assets change after the trustees and principles' rating change, small loan company should choose the service management institution with high credit rating and good reputation, thus reducing the risk caused by institution itself as much as possible.

Anyhow, asset securitization is a good choice for the small loan companies to resolve the funds shortage problem. The risk management of assets securitization helps small loan companies get the benefits at the same time reduces risk severity and probability, thus promoting the sustainable development of small loan companies in China.

\section{ACKNOWLEDGEMENT}

This research was financially supported by National Social Science Foundation Project (13CJY077), Xi'an Social Science Foundation Project (16J101); Northwest University Graduate Innovation Project (YZZ15051).

\section{REFERENCES}

[1] Lewis S., Ranie with the Wall Street journal reporter in discussing mortgage sold securities for the first time to use the term "asset securitization", 1977.

[2] Steven L.Schwarc2, "The Alchemy of Asset Securitization", .1Stan. J. LBus\&Fin.1, 1994, pp. 944-133.

[3] Claire Securitization, "A Low Cost Sweetener for Lemons", 74 Wash, 1996, pp. 1061-1120.

[4] Shenker, J.C. and A.J. Colletta, "Asset Securitization: Evolution, Current Issues and New Frontiers", Tex. L. Rev., 1990, vol. 69 , p.1369.

[5] Benveniste, L.M. and A.N. Berger, "Securitization with recourse: An instrument that offers uninsured bank depositors sequential claims ", Journal of Banking \& Finance, vol.11, no. 3, pp. 403-424, 1987.

[6] Jiang jianqing, "Commercial bank asset securitization from money market to capital market", Beijing: China financial publishing house, China, 2004, pp.308-300.

[7] Dunsky R M, "Valuing Fixed Rate Mortgage Loans with Default and PrepaymentOptions", Journal of Fixed Income, vol. 16, pp. 7-31, 2007.

[8] Sharp N J, Duck P, Newton N., “An improved fixed-rate mortgage valuation metiiodology with interacting prepayment and default 
options", The Journal of Real Estate Finance and Economics, vol.3 pp.307-342, 2008.

[9] Tao Tao, "The analysis of bank credit asset securitization risk control-based on the analytic hierarchy process (ahp)", Journal of statistics and decision, vol.6, pp.162-16, 2013.

[10] Zhong-he tian, Guo Xin, "The application of VAR in the asset securitization risk analysis", Journal of research and development, vol. 2, pp.120-123, 2012. 